\title{
Proximate and Cardiac Glycoside Composition of Thevetia (Thevetia neriifolia. JUSS) Seed as Affected by Soaking in Water, Brine and Ethanol
}

\author{
B. O. Ayinde ${ }^{1}$, O. A. Ogunwole ${ }^{1}$, B. C. Majekodunmi ${ }^{1} \&$ I. Oikeh ${ }^{1}$ \\ ${ }^{1}$ Animal Nutrition Unit, Department of Animal Science, University of Ibadan, Ibadan, Nigeria \\ Correspondence: O. A. Ogunwole, Animal Nutrition Unit, Department of Animal Science, University of Ibadan, \\ Ibadan, Nigeria. E-mail: droaogunwole@gmail.com
}

Received: August 9, 2013 Accepted: September 14, 2013 Online Published: October 15, 2013

doi:10.5539/jas.v5n11p201～URL: http://dx.doi.org/10.5539/jas.v5n11p201

\begin{abstract}
Effects of soaking using water, ethanol and brine on proximate and cardiac glycoside composition of Thevetia neriifolia seed (TS) were undertaken. Each $100 \mathrm{~g}$ portion of TS was soaked in either water or ethanol for 24 hours or in $2.5,5.0$ and $7.5 \%$ brine solution for 2,3 or 4 hours. The samples were then either sun-dried for 3 days or toasted after soaking and thereafter analyzed for chemical and residual glycoside composition. There were significant $(\mathrm{P}<0.05)$ variations in the composition of ash which ranged from $13.0 \%$ in the raw meal $\left(\mathrm{T}_{\mathrm{R}}\right)$ to $11.04 \%$ in $\mathrm{T}_{4}$ (TS soaked in fine-grade ethanol and sun-dried). Obtained values for nitrogen free extracts was between $12.56 \%$ in $\mathrm{T}_{1}$ (TS soaked in water and toasted) and $28.31 \%$ in $\mathrm{T}_{4}$. These values varied significantly $(\mathrm{P}<0.05)$ among the groups except in $\mathrm{T}_{2}$ (TS soaked in water and sun-dried) (19.47\%) and $\mathrm{T}_{3}$ (TS soaked in fine-grade ethanol and toasted) $(20.09 \%)$ where the values were similar $(\mathrm{P}>0.05)$. Toasting significantly $(\mathrm{P}<0.05)$ reduced the crude protein $(\mathrm{CP})$ in water and ethanol treated samples from $19.35 \%$ in raw sample to 18.14 and $18.43 \%$, respectively. The CP increased significantly in sun-dried water $(22.1 \%)$ and brine treated $(23.1 \%)$ samples. Soaking in $7.5 \%$ brine for 3 hours significantly $(\mathrm{P}<0.05)$ reduced glycoside content from $4.7 \%$ to $0.07 \%(98.51 \%$ reduction of glycoside).
\end{abstract}

Keywords: residual cardiac glycoside content, thevetia seed proximate composition, potential oilseed cake, feedstuff detoxification, thevetia seed meal.

\section{Introduction}

Animal nutritionist have not relented in their quest to explore and establish the potential of other numerous and lesser known plant and animal products as feed ingredients in livestock industry. Nutritional properties of plants and animal products such as pigeon pea, lima beans, cottonseed, sunflower, locust bean, cassava peel, feather meal, and blood meal have been elucidated through meaningful research to reduce or totally remove the toxins and anti-metabolites in them thereby making the feedstuff more important particularly as ingredients in livestock feed formulation. (Akande, 2009; Akande et al., 2010; Akintunde et al., 2010).

The plant Thevetia neriifolia (Juss) grows wild in the humid zone of West Africa including Nigeria. Also known as yellow oleander, milk bush, trumpets flower or best still tree that belongs to the family apocynaceae. It is a perennial shrub, $6 \mathrm{~m}$ in height, native of central and tropical South America and named after the French monk F. Andre Thevet (1502-1592) (Burrkilol, 1985). It is an ornamental plant propagated for its flowers and used mainly as hedge plant. Cake contains 30-53\% protein (Steintz, 1962; Ibiyemi et al., 2002; Oluwaniyi et al., 2007). The seed contains $60-65 \%$ oil while the defatted cake contains $30-53 \%$ protein (Steintz, 1962; Ibiyemi et al., 2002; Oluwaniyi et al., 2007)

Documentation of the nutritive potentials of TS has been very scanty. Atteh et al. (1990) investigated the replacement value of Thevetia oil for palm oil in broiler chicks' diets and recommended further processing of the oil prior to its being used effectively as a feed ingredient. Oderinde and Oladimeji (1990) analyzed the composition of the oil and indicated a total unsaturated fatty acids of $75.4 \%$ of which oleic acid was $31.46 \%$ and linoleic acid $43.90 \%$. It has the characteristic of good edible oil, if the bitterness could be removed by alumina and alkali treatment. Various ways of eliminating toxic components and improving the nutritive value of feedstuff like fermentation, ensiling, sun drying, oven drying, boiling, soaking in water or other solvents, autoclaving and so on 
depending on the nature of the substrate have been documented (Verma, 2006; Olomu, 2011; Vasudevan et al., 2011).

Recent efforts directed towards detoxification of the seed for inclusion into the diets of one or two classes of livestock (Ibiyemi \& Oluwaniyi, 2003; Oluwaniyi et al., 2007) met with some degree of success. The practicality of the methods of detoxification employed (in terms of cost and expertise) among the targeted clientele (local poultry farmers) left much to be desired. In a bid to detoxify Thevetia seeds, a method of detoxification that would significantly increase the cost of production would be undesirable, as was the case with the alcoholic extraction (Oluwaniyi et al., 2007). In addition, the process must be practicable in terms of technicality and handling by local farmers that would be the main user of the method.

The present endeavor was aimed at investigating the effects of soaking using water, ethanol and brine on the proximate and cardiac glycoside composition of Thevetia neriifolia seed.

\section{Materials and Methods}

Thevetia neriifolia fruits that have fallen off plants and turned black due to decomposition of the pericarp were handpicked and manually cracked to remove the soft seeds. The picking and cracking of fruits were done concurrently within the duration of a week in Ado-odo / Ota Local Government area of Ogun State, Nigeria. The choice of fruits that have fallen off plant was to be sure that only matured fruits were selected.

Four portions of TS weighing $100 \mathrm{~g}$ each were either soaked in water or fine grade ethanol for three days (72 hours) as described by Oluwaniyi and Ibiyemi (2007).The extracts were then drained and the seeds were either sun-dried or toasted for subsequent analysis residual glycoside content.

Other portions weighing $100 \mathrm{~g}$ each were soaked in brine solution of three different graded concentrations of 2.5, 5.0 and $7.5 \%$ for 2,3 and 4 hours concurrently at room temperature with intermittent stirring. The extract were thereafter drained and the residues sun-dried until friable and then stored for analyses. A portion of raw seeds weighing $100 \mathrm{~g}$ was also milled and stored for analyses.

\subsection{Chemical Analyses}

Proximate analysis of all samples was determined according to AOAC (2000). The cardiac glycosides in raw and treated sampled of the extract was evaluated using a modification of El-Olemy et al. (1994). The gross energy was calculated based in the procedure of Ekanayake et al. (1999) and the metabolizable energy value of the samples was estimated according to the procedure of Pauzenga (1985).

\subsection{Statistical Analysis}

Data were analyzed using SAS (1999) to estimate the variances and significant variations compared using Duncan multiple range test of the same software.

\section{Results}

The proximate composition of raw, water and ethanol-detoxified TS is summarized in Table 1. Dry matter content significantly $(\mathrm{P}<0.05)$ increased in the toasted samples $\left(\mathrm{T}_{1}\right.$ and $\left.\mathrm{T}_{3}\right)$ from $88.60 \%$ in raw sample $\left(\mathrm{T}_{\mathrm{R}}\right)$ to $90.40 \%$ in $\mathrm{T}_{1}$ and $91.02 \%$ in $\mathrm{T}_{3}$. The CP content decreased significantly $(\mathrm{P}<0.05)$ from $19.35 \%$ in raw sample to $18.14 \%$ in $\mathrm{T}_{1}$ (TS soaked in water and toasted) and $18.43 \%$ in $\mathrm{T}_{3}$, but $\mathrm{T}_{2}$ (TS soaked in water and sun-dried) had significantly $(\mathrm{P}<0.05)$ higher value of $22.11 \%$.

A similar trend was observed for crude fibre (CF), with a drop from $6.56 \%$ in $\mathrm{T}_{\mathrm{R}}$ to $5.62 \%$ in $\mathrm{T}_{1}$. However, variations observed for $\mathrm{CF}$ in $\mathrm{T}_{2}, \mathrm{~T}_{3}$ and $\mathrm{T}_{4}$ were not significant $(\mathrm{P}>0.05)$. The lowest $(\mathrm{P}<0.05)$ value of $35.20 \%$ for ether extract was observed for $\mathrm{T}_{3}$ (TS soaked in fine-grade ethanol and toasted) but this value was not significantly $(\mathrm{P}>0.05)$ different from the value observed for $\mathrm{T}_{4}$ (TS soaked in fine-grade ethanol and sun-dried). However, the variations observed for ether extract for $T_{1}, T_{2}$, and $T_{3}$ were not significant $(P>0.05)$. There were significant $(\mathrm{P}<0.05)$ variations in the composition of ash. Mean values obtained ranged from $13.0 \%$ in the raw meal $\left(\mathrm{T}_{\mathrm{R}}\right)$ to $11.04 \%$ in $\mathrm{T}_{4}$ (TS soaked in fine-grade ethanol and sun-dried). Treatments 1 and $2\left(\mathrm{~T}_{1}\right.$ and $\left.\mathrm{T}_{2}\right)$ however, were statistically similar. Values obtained for nitrogen free extracts ranged from $12.56 \%$ in $\mathrm{T}_{1}$ to $28.31 \%$ in $\mathrm{T}_{4}$. These values varied significantly $(\mathrm{P}<0.05)$ among the groups except in $\mathrm{T}_{2}(19.47 \%)$ and $\mathrm{T}_{3}(20.09 \%)$ where variations were not significant $(\mathrm{P}>0.05)$. There was a general decrease in gross energy from $5.94 \mathrm{kcal} / \mathrm{g}$ DM in the raw sample $T_{R}$ to $5.02 \mathrm{kcal} / \mathrm{g}$ DM in $T_{4}$ but the apparent differences observed between $T_{R}$ and $T_{2}$ were not significant $(\mathrm{P}>0.05)$.

Results obtained for the level of glycoside in treated and untreated TS were shown in Table 2. The level of glycoside significantly reduced from $47.2 \mathrm{~g} / \mathrm{kg}$ in the raw sample $\left(\mathrm{T}_{\mathrm{R}}\right.$ ) to $0.08 \mathrm{~g} / \mathrm{kg}$ in $\mathrm{T}_{3}$ (TS soaked in fine-grade ethanol and toasted) which was about $98.3 \%$ reduction in glycoside composition. The reduction in glycoside 
composition in water treated samples $\mathrm{T}_{1}$ (TS soaked in water and toasted) and $\mathrm{T}_{2}$ (TS soaked in water and sun-dried) was $41.28 \%$ and $45.74 \%$ respectively. Differences observed in values for water treated and ethanol treated samples were significant $(\mathrm{P}<0.05)$. The values observed for ethanol treated samples $\mathrm{T}_{3}$ (TS soaked in fine-grade ethanol and toasted) and $\mathrm{T}_{4}$ (TS soaked in fine-grade ethanol and sun-dried) were 0.08 and 0.09 about $98.30 \%$ and $98.09 \%$ respectively.

Table 1. Proximate composition $(\mathrm{g} / 100 \mathrm{~g})$ of raw and detoxified Thevetia seed

\begin{tabular}{lllllll}
\hline \multirow{2}{*}{ Nutrients } & \multicolumn{5}{c}{ Treatments } \\
\cline { 2 - 7 } & $\mathrm{T}_{\mathrm{R}}$ & $\mathrm{T}_{1}$ & $\mathrm{~T}_{2}$ & $\mathrm{~T}_{3}$ & $\mathrm{~T}_{4}$ & $\mathrm{SEM}$ \\
\hline Crude protein (\%) & $19.35^{\mathrm{b}}$ & $18.14^{\mathrm{d}}$ & $22.11^{\mathrm{a}}$ & $18.43^{\mathrm{d}}$ & $18 . .86^{\mathrm{c}}$ & 0.08 \\
Crude fibre (\%) & $6.56^{\mathrm{a}}$ & $5.62^{\mathrm{c}}$ & $6.16^{\mathrm{b}}$ & $6.04^{\mathrm{b}}$ & $6.12^{\mathrm{b}}$ & 0.06 \\
Ether extract (\%) & $44.01^{\mathrm{a}}$ & $42.02^{\mathrm{a}}$ & $40.12^{\mathrm{a}}$ & $35.20^{\mathrm{b}}$ & $35.67^{\mathrm{b}}$ & 1.21 \\
Ash (\%) & $13.00^{\mathrm{a}}$ & $12.06^{\mathrm{b}}$ & $12.14^{\mathrm{b}}$ & $11.26^{\mathrm{c}}$ & $11.04^{\mathrm{c}}$ & 0.08 \\
Nitrogen free extract (\%) & $17.08^{\mathrm{c}}$ & $12.56^{\mathrm{d}}$ & $19.47^{\mathrm{b}}$ & $20.09^{\mathrm{b}}$ & $28.31^{\mathrm{a}}$ & 0.17 \\
Dry matter (\%) & $88.60^{\mathrm{b}}$ & $90.40^{\mathrm{a}}$ & $87.11^{\mathrm{c}}$ & $91.02^{\mathrm{a}}$ & $86.22^{\mathrm{d}}$ & 0.23 \\
Gross energy (kcal/g DM) & $5.94^{\mathrm{a}}$ & $5.20^{\mathrm{b}}$ & $5.89^{\mathrm{a}}$ & $5.11^{\mathrm{b}}$ & $5.02^{\mathrm{b}}$ & 0.10 \\
\hline
\end{tabular}

a,b,c,d- Means along the same row with any identical superscripts are not significantly different $(\mathrm{P}>0.05) ; \mathbf{T}_{\mathbf{R}}=$ untreated TS; $\mathrm{T}_{1}=$ Thevetia seed (TS) soaked in water and toasted; $\mathrm{T}_{2}=\mathrm{TS}$ soaked in water and sun-dried; $\mathrm{T}_{3}=\mathrm{TS}$ soaked in fine-grade ethanol and toasted; $\mathrm{T}_{4}=\mathrm{TS}$ soaked in fine-grade ethanol and sun-dried. SEM $=\mathrm{Standard}$ Error of Means; DM = Dry matter.

Table 2. Glycoside content of raw and treated Thevetia seed

\begin{tabular}{ccc}
\hline Sample & Total glycoside (\%) & Reduction in glycoside level (\%) \\
\hline $\mathrm{T}_{\mathrm{R}}$ & $4.70^{\mathrm{a}}$ & $0.00^{\mathrm{c}}$ \\
$\mathrm{T}_{1}$ & $2.76^{\mathrm{b}}$ & $41.28^{\mathrm{b}}$ \\
$\mathrm{T}_{2}$ & $2.55^{\mathrm{b}}$ & $45.74^{\mathrm{b}}$ \\
$\mathrm{T}_{3}$ & $0.08^{\mathrm{c}}$ & $98.30^{\mathrm{a}}$ \\
$\mathrm{T}_{4}$ & $0.09^{\mathrm{c}}$ & $98.09^{\mathrm{a}}$ \\
$\mathrm{SEM}$ & 0.56 & 3.45
\end{tabular}

Values were means of three determinations. a, b, c means along the same row with any identical superscript are not significantly different $(\mathrm{p}>0.05)$. SEM $=$ Standard error of means.

The proximate composition of brine-treated Thevetia seed is shown in Table 3 . There were significant $(p<0.05)$ differences in the mean values observed for crude protein. Crude protein, significantly $(\mathrm{p}<0.05)$ increased in all brine-treated samples. The observed mean values for crude protein ranged from $23.20 \%$ in $\mathrm{B}_{4}$ (TS soaked in $5.0 \%$ brine for 4 hours) to $19.36 \%$ in the raw sample $\mathrm{T}_{\mathrm{R}}$. The apparent variations observed for brine-treated samples $\mathrm{A}_{3}$ (TS soaked in $2.5 \%$ brine for 3 hours), $\mathrm{A}_{4}$ (TS soaked in $2.5 \%$ brine for 4 hours), $\mathrm{B}_{2}$ (TS soaked in $5.0 \%$ brine for 2 hours), $\mathrm{B}_{3}$ (TS soaked in 5.0\% brine for 3 hours), $\mathrm{B}_{4}$ (TS soaked in 5.0\% brine for 4 hours), $\mathrm{C}_{2}$ (TS soaked in $7.5 \%$ brine for 2 hours), $\mathrm{C}_{3}$ (TS soaked in $7.5 \%$ brine for 3 hours) and $\mathrm{C}_{4}$ (TS soaked in $7.5 \%$ brine for 4 hours) were not significant $(\mathrm{p}>0.05)$.

Observed values for crude fibre ranged from $6.56 \%$ in raw sample $\mathrm{T}_{\mathrm{R}}$ to $5.25 \%$ in $\mathrm{B}_{4}$ (TS soaked in $5.0 \%$ brine for 4 hours). These variations were however not significant $(\mathrm{p}>0.05)$. Composition of ether extractives varied significantly $(\mathrm{p}<0.05)$ from $44.01 \%$ in raw sample to $32.75 \%$ in $\mathrm{A}_{4}$ (TS soaked in $2.5 \%$ brine for 4 hours). The variations observed in $\mathrm{A}_{4}$ (TS soaked in $2.5 \%$ brine for 4 hours), $\mathrm{B}_{4}$ and $\mathrm{C}_{4}$ were not significant ( $\mathrm{p}>0.05$ ). Similarly, the variations observed for $A_{2}, A_{3}, B_{2}, B_{3}, C_{2}$ and $C_{3}$ were not significant $(p>0.05)$. Observed values for ash ranged from $15.20 \%$ in $\mathrm{C}_{4}$ (TS soaked in $7.5 \%$ brine for 4 hours) to $13.00 \%$ in raw sample $\mathrm{T}_{\mathrm{R}}$. Apparent variations observed in values for $\mathrm{A}_{3}, \mathrm{~A}_{4}, \mathrm{~B}_{2}, \mathrm{~B}_{3}$ and $\mathrm{B}_{4}$ were not significant $(\mathrm{P}>0.05)$. Similarly, the apparent variations observed in values for $\mathrm{C}_{2}, \mathrm{C}_{3}$ and $\mathrm{C}_{4}$ were not significant $(\mathrm{p}>0.05)$, but significantly $(\mathrm{P}<0.05)$ higher than values 
observed for $\mathrm{A}_{2}$ (TS soaked in $2.5 \%$ brine for 2 hours) and TR (raw sample) which are $13.89 \%$ and $13.00 \%$ respectively.

Observed values for nitrogen free extractives ranged from $24.35 \%$ in B4 (TS soaked in $5.0 \%$ brine for 4 hours) to $15.56 \%$ in $\mathrm{C}_{2}$ (TS soaked in $7.5 \%$ brine for 2 hours). Values observed for $\mathrm{A}_{4}, \mathrm{~B}_{4}$ and $\mathrm{C}_{4}(24.04 \%, 24.35 \%$ and $23.13 \%$ respectively) were not significantly $(\mathrm{P}>0.05)$ different among these groups but significantly $(\mathrm{P}<0.05)$ higher than those observed for other treatments.

Table 3. Proximate composition of brine-treated Thevetia seeds

\begin{tabular}{llllllllllll}
\hline Nutrients (\%) & $\mathrm{A}_{2}$ & $\mathrm{~A}_{3}$ & $\mathrm{~A}_{4}$ & $\mathrm{~B}_{2}$ & $\mathrm{~B}_{3}$ & $\mathrm{~B}_{4}$ & $\mathrm{C}_{2}$ & $\mathrm{C}_{3}$ & $\mathrm{C}_{4}$ & Raw & SEM \\
\hline Crude protein & $20.1^{\mathrm{b}}$ & $23.1^{\mathrm{a}}$ & $23.2^{\mathrm{a}}$ & $23.1^{\mathrm{a}}$ & $23.1^{\mathrm{a}}$ & $23.2^{\mathrm{a}}$ & $23.0^{\mathrm{a}}$ & $23.1^{\mathrm{a}}$ & $23.2^{\mathrm{a}}$ & $19.4^{\mathrm{b}}$ & 2.5 \\
Crude fibre & 6.1 & $5.7^{1}$ & 5.8 & $5.8^{3}$ & 5.6 & $5.3^{3}$ & 5.9 & 5.7 & 5.7 & 6.6 & 2.1 \\
Ether extract & $42.9^{\mathrm{b}}$ & $38.4^{\mathrm{b}}$ & $32.8^{\mathrm{c}}$ & $40.7^{\mathrm{b}}$ & $38.4^{\mathrm{b}}$ & $32.8^{\mathrm{c}}$ & $40.6^{\mathrm{b}}$ & $38.4^{\mathrm{b}}$ & $32.8^{\mathrm{c}}$ & $44.0^{\mathrm{a}}$ & 1.1 \\
Ash & $13.9^{\mathrm{c}}$ & $14.3^{\mathrm{b}}$ & $14.3^{\mathrm{b}}$ & $14.4^{\mathrm{b}}$ & $14.4^{\mathrm{b}}$ & $14.4^{\mathrm{b}}$ & $15.0^{\mathrm{a}}$ & $15.2^{\mathrm{a}}$ & $15.2^{\mathrm{a}}$ & $13.0^{\mathrm{c}}$ & 2.1 \\
NFE & $17.0^{\mathrm{b}}$ & $18.7^{\mathrm{b}}$ & $24.0^{\mathrm{a}}$ & $16.1^{\mathrm{c}}$ & $18.5^{\mathrm{b}}$ & $24.4^{\mathrm{a}}$ & $15.6^{\mathrm{c}}$ & $17.6^{\mathrm{b}}$ & $23.1^{\mathrm{a}}$ & $17.1^{\mathrm{b}}$ & 2.1 \\
Dry matter & 88.8 & 88.8 & 88.9 & 88.8 & 88.9 & 88.9 & 88.9 & 88.9 & 88.9 & 88.6 & 1.1 \\
Moisture & 11.3 & 11.2 & 11.1 & 11.2 & 11.1 & $11.2^{1}$ & 11.2 & 11.1 & 11.0 & 11.4 & 0.9
\end{tabular}

$\mathrm{a}, \mathrm{b}, \mathrm{c}, \mathrm{d}=$ means along the same row with identical superscripts were not significantly different $(\mathrm{p}>0.05)$; Raw $=$ Untreated Thevetia Seed, $A_{2}=$ Solution A $+100 \mathrm{~g}$ Thevetia Seed soaked for 2 hours; $A_{3}=$ Solution A $+100 \mathrm{~g}$ Thevetia Seed soaked for 3 hours , $A_{4}=$ Solution $A+100 g$ Thevetia Seed soaked for 4 hours; $B_{2}=$ Solution $B+$ $100 \mathrm{~g}$ Thevetia Seed soaked for 2 hours, $\mathrm{B}_{3}=$ Solution B $+100 \mathrm{~g}$ Thevetia Seedl soaked for 3 hours; $\mathrm{B}_{4}=$ Solution $\mathrm{B}+100 \mathrm{~g}$ Thevetia Seed soaked for 4 hours, $\mathrm{C}_{2}=$ Solution $\mathrm{C}+100 \mathrm{~g}$ Thevetia Seed soaked for 2 hours; $\mathrm{C}_{3}=$ Solution C $+100 \mathrm{~g}$ Thevetia Seed soaked for 3 hours, $\mathrm{C}_{4}=$ Solution C $+100 \mathrm{~g}$ Thevetia Seed soaked for 4 hours; A $=2.5 \%$ Sodium Chloride Solution., $\mathrm{B}=5.0 \%$ Sodium Chloride Solution,. $\mathrm{C}=7.5 \%$ Sodium Chloride Solution Figures 2, 3 and 4 stood for time in hours. NFE= Nitrogen Free Extract.

$\mathrm{SEM}=$ Standard error of means.

$\mathrm{TSM}=$ Thevetia seed meal.

\subsection{Glycoside Level of Brine-Treated Thevetia Seeds}

The level of cardiac glycoside (measured as digitoxin) in the samples is summarised in Table 4. Glycoside content of brine-treated samples significantly $(\mathrm{P}<0.05)$ reduced from $4.70 \%$ in the raw meal to $0.07 \%$ in $\mathrm{C}_{3}$ (TS soaked in $7.5 \%$ brine for 3 hours). There was also a marked reduction in glycoside level in samples $\mathrm{A}_{3}$ (TS soaked in $2.5 \%$ brine for 3 hours) and $\mathrm{B}_{2}$ (TS soaked in $5.0 \%$ brine for 2 hours), $(0.21 \%$ and $0.41 \%$ respectively).The level of glycoside reduction observed for samples $A_{3}, B_{2}$ and $C_{3}$ were not significant but the value observed for $C_{3}$ was the lowest, even below what was observed for the ethanol treated samples $\mathrm{T}_{3}$ (TS soaked in fine-grade ethanol and toasted) and $\mathrm{T}_{4}$ (TS soaked in fine-grade ethanol and sun-dried). Percentage reduction in glycoside composition ranged from $63.40 \%$ in $\mathrm{C}_{4}$ (TS soaked in $7.5 \%$ brine for 4 hours) to $98.51 \%$ in $\mathrm{C}_{3}$ (TS soaked in $7.5 \%$ brine for 3 hours). The highest value of $98.51 \%$ observed for $\mathrm{C}_{3}$ was closely followed by $95.53 \%$ and $91.28 \%$ for $\mathrm{A}_{3}$ and $\mathrm{B}_{2}$ respectively. The observed value for percentage glycoside significantly $(\mathrm{P}<0.05)$ dropped from $75.53 \%$ in $\mathrm{C} 2$ (TS soaked in $7.5 \%$ brine for 2 hours) to $63.40 \%$ in $\mathrm{C}_{4}$, however values observed for $\mathrm{B}_{4}$ (TS soaked in $5.0 \%$ brine for 4 hours) and $\mathrm{C}_{2}$ were not significantly different $(\mathrm{P}>0.05)$ 
Table 4. Glycoside Level of brine-detoxified Thevetia seed

\begin{tabular}{ccc}
\hline Sample & Glycoside level (\%) & Glycoside Reduction (\%) \\
\hline Raw & $4.70^{\mathrm{a}}$ & 0.00 \\
$\mathrm{~A}_{2}$ & $0.48^{\mathrm{d}}$ & 89.79 \\
$\mathrm{~A}_{3}$ & $0.21^{\mathrm{f}}$ & 95.53 \\
$\mathrm{~A}_{4}$ & $0.66^{\mathrm{d}}$ & 85.96 \\
$\mathrm{~B}_{2}$ & $0.41^{\mathrm{f}}$ & 91.28 \\
$\mathrm{~B}_{3}$ & $0.68^{\mathrm{d}}$ & 85.53 \\
$\mathrm{~B}_{4}$ & $1.09^{\mathrm{c}}$ & 76.81 \\
$\mathrm{C}_{2}$ & $1.15^{\mathrm{c}}$ & 75.53 \\
$\mathrm{C}_{3}$ & $0.07^{\mathrm{f}}$ & 98.51 \\
$\mathrm{C}_{4}$ & $1.72^{\mathrm{b}}$ & 63.40 \\
\hline
\end{tabular}

$a, b, c, d=$ means along the same row with any identical superscript are not significantly different $(p>0.05)$; Raw $=$ Untreated Thevetia seed, $A_{2}=$ Solution $A+100 \mathrm{~g}$ Thevetia Seed soaked for 2 hours. $A_{3}=$ Solution $A+100 g$ Thevetia Seed soaked for 3 hours, $A_{4}$ solution $A+100 g$ Thevetia Seed soaked for 4 hours. $B_{2}=$ Solution $B+100 g$ Thevetia Seed soaked for 2 hours; $B_{3}=$ Solution B $+100 \mathrm{~g}$ Thevetia Seed soaked for 3 hours; $\mathrm{B}_{4}=$ Solution B + $100 \mathrm{~g}$ Thevetia Seed soaked for 4 hours; $C_{2}=$ Solution C $+100 \mathrm{~g}$ Thevetia seed for 2 hours; $C_{3}=$ Solution $C+100 \mathrm{~g}$ Thevetia Seed soaked for 3 hours; $\mathrm{C}_{4}=$ Solution $\mathrm{C}+100 \mathrm{~g}$ Thevetia seed soaked for 4 hours. The alphabet stands for the concentration of brine and the number stands for time in hours. $\mathrm{A}=2.5 \%$ Sodium Chloride solution; $\mathrm{B}=5.0 \%$ Sodium Chloride solution; $\mathrm{C}=7.5 \%$ Sodium Chloride solution.

\subsection{Proximate Composition of Defatted TSM}

Table 5 shows the summary of the proximate composition of TSM after extracting oil from it. The two methods of oil extraction employed gave significant variations $(\mathrm{P}>0.05)$ in the values recorded for all the nutrient components except for $\mathrm{CF}$, ash and dry matter. Crude protein significantly $(\mathrm{P}<0.05)$ increased from $27.20 \%$, with hydraulic extraction to $44.8 \%$, with expeller extraction. Ether extract significantly reduced from $28.5 \%$ with hydraulic extraction to $5.1 \%$ with expeller. The observed variations in the mean value for $C F$, were not significant $(\mathrm{P}>0.05)$. CF increased from $13.8 \%$ with hydraulic extraction to $14.2 \%$ with expeller. The composition of ash dropped $(\mathrm{P}>0.05)$ from $8.0 \%$ with hydraulic extraction to $7.7 \%$ with expeller. Percentage NFE significantly $(\mathrm{P}<0.05)$ increased from $18.5 \%$ with hydraulic extraction to $255.3 \%$ with expeller. The method of oil extraction had no significant $(\mathrm{P}>0.05)$ effect on the percentage $\mathrm{DM}$.

Table 5. Proximate Composition (g/100g DM) of Defatted Thevetia Seed Meal

\begin{tabular}{llll}
\hline Nutrient (\%) & Hydraulic & Expeller & SEM \\
\hline Crude protein & $27.2^{\mathrm{b}}$ & $44.8^{\mathrm{a}}$ & 2.16 \\
Ether extract & $28.5^{\mathrm{a}}$ & $5.1^{\mathrm{b}}$ & 2.05 \\
Crude fibre & 13.8 & 14.2 & 0.34 \\
Ash & 8.0 & 7.7 & 0.41 \\
NFE & $18.5^{\mathrm{b}}$ & $25.3^{\mathrm{a}}$ & 1.94 \\
Dry matter & 96.0 & 97.2 & 3.85 \\
\hline
\end{tabular}

$\mathrm{NFE}=$ Nitrogen Free Extract; $\mathrm{SEM}=$ Standard error of means; $\mathrm{a}, \mathrm{b}, \mathrm{c}, \mathrm{d}=$ means along the same row with any identical superscript are not significantly different $(\mathrm{p}>0.05)$.

\section{Discussion}

The processing methods used in this study resulted in a decreased crude protein content of the treated samples except for $\mathrm{T}_{2}$ and the brine-treated samples where CP significantly increased from $19.35 \%$ in the raw sample to $22.11 \%$ in $\mathrm{T}_{2}$ (soaked in water and sun-dried) and $23.2 \%$ in $\mathrm{C}_{3}(7.5 \%$ brine). The changes observed especially in 
sun-cured samples must have been due to activities of microorganisms during soaking (fermentation) and sun-curing which perhaps resulted in biochemical changes and significant modification of food quality as earlier reported (Campbell \& Laherrere, 1998). This also revealed that fermentation could improve the nutritive qualities of food in both plant and animal tissues. The decrease in percentage $\mathrm{CP}$ for the toasted samples could be attributed to the negative impact of heat on proteins as reported elsewhere. (Vasudevan et al., 2011). The percentage composition of nutrients especially $\mathrm{CP}$ recorded in this study was below the values reported by Oluwaniyi et al. (2007). This could be due to differences in the location of the source of Thevetia seeds and methods of detoxification employed.The reduction in the level of cardiac glycoside measured as percentage digitoxin in all treatments agreed with other reports [Chen \& Chen, 1933; Bai \& Koshy, 1999] that glycosides of Thevetia were water and alcohol soluble as well those glycosides were more soluble in ethanol than in water. In the present study, water-extracted TS recorded $45.74 \%$ reduction in the level of glycoside compared to the raw sample, while ethanol extraction was $98.30 \%$. The undesirable cost associated with the use of ethanol in the first trial gave rise to the use of brine as extracting solvent. Brine- treatment recorded a higher percentage $(98.51 \%)$ reduction of glycoside in $\mathrm{C}_{3}$ (7.5\% brine soaked for three hours) compared to ethanol-treatment. This conformed to the report of Desai (2000) that cardiac glycosides have affinity for $\mathrm{Na}^{+}$and/or $\mathrm{K}^{+}$contained in brine. The reversal of the reaction after three hours could be attributed to lack of $\mathrm{Na}^{+}$ions in the solution to combine with thevetin in the presence of ATPase resulting in a relapse of the reaction. Oil extraction increased the percentage CP of detoxified TSM. The CP of full-fat TSM increased from $23.12 \%$ in $\mathrm{C}_{3}$ to 27.2 and $44.8 \%$ in the hydraulic and expeller- extracted samples respectively. This agreed with other earlier reports [Finnigan and Lewis, 1988; Lutz and Pryztulski, 2008] in which $\mathrm{CP}$ of oilseeds tends to increase when the oil content was reduced considerably. The differences observed in the nutrient composition of the cake from the two methods employed could be as a result of the fact that the proteins got more concentrated as more oil was extracted by the expeller method. This therefore suggested the superiority of electrical power over hydraulic press.

\section{Conclusion}

Thevetia seed when processed has favourable nutritional profile utilizable in the diets of farm animals. Soaking in brine reduced cardiac glycoside content more effectively when compared with either water or alcohol. Thus, the use of brine was relatively much easier and less expensive compared to ethanol.

\section{References}

Association of Official Analytical Chemists (AOAC). (2000). Official methods of analysis (17th Ed.). Washington, DC.

Akande, K. E. (2009). Effect of some unconventional protein sources on the performance, Nutrient digestibility and carcass characteristics of rabbits. Ph.D. Thesis, Abubakar Tafawa Balewa University, Bauchi, Nigeria.

Akande, K. E., Abubakar, M. M., Adegbola, T. A., Bogoro, S. E., \& Doma, U. D. (2010). Origin and uses of some unconventional protein sources. Proceedings of 35th Conference of Nigeria Society for Animal Production (pp. 433-435). 14-17 March, 2010. University of Ibadan, Nigeria.

Akintunde, A. R., Omage, J. J., \& Bawa, G. S. (2010). Effects of allzyme supplementation on the utilization of differently processed pigeon pea (Cajanus cajan) seeds by broiler chickens. Proceedings of $35^{\text {th }}$ Conference of Nigeria Society For Animal Production (pp. 439-442). 14-17 March, 2010. University of Ibadan, Nigeria.

Atteh, J. O., Ibiyemi, S. A., Onadepo, T. A., \& Ugboma, O. O. (1990). Replacement of Palm Oil by Thevetia oil in broiler chicks diets. Journal of Agricultural Science Cambridge, 115(1), 141-143. http://dx.doi.org/10.1017/S0021859600074037

Bai, H., \& Koshy, G. (1999). Yellow oleander (Thevetia neriifolia Juss) a bio- antifeedant for Epilachna beetle (Henosepiladina viginitioctopunetata L). Journal of Tropical Agriculture (India), 37(1-2), 64-67.

Burkill, H. M. (1985). The Useful Plant of West Tropical Africa (Vol. 1, families A-D p. 189, 2nd Ed.). Royal Botanic Gardens KEW.

Campbell, C. J., \& Laherrere, J. H. (1998). The end of cheap oil. Science Am., 3, 78-83. http://dx.doi.org/10.1038/scientificamerican0398-78

Chen, K. K., \& Chen, A. L. (1933). The Constituents of Be-Still Nuts, Thevetia neriifolia. Journal of Biological Chemistry, 105(2), 231-238.

Desai, U. R. (2000). Cardiac Glycosides. Retrieved from http://dx.doi.www.people.vcu.edu/ urdesai/car.htm

Duncan, B. D. (1955). Multiple Range Test and Multiple F-test. Biometrics, 11, 1-42. http://dx.doi.org/10.2307/3001478 
Ekanayake, S., Jansz, E. R., \& Nair, B. M. (1999). Proximate compositions, mineral and amino Acid content of mature Canavalia gladiata seeds. Food Chemistry, 66, 115-119. http://dx.doi.org/10.1016/S0308-8146(99)00041-2

El-Olemy, M. M, Al-Muhtadi, F. J., \& Afifi, A. F. A. (1994). Experimental Phytochemistry: A laboratory manual (pp. 21-27). Saudi Arabia: King Saud University Press.

Finnigan, T. J. A., \& Lewis, M. J. (1988). Ethanolic Extraction of Commercial Rapeseed Meal in the Production of Protein Concentrate of Reduced Glucosinolate Content. Journal of Science Food and Agriculture, 45, 155-163. http://dx.doi.org/10.1002/jsfa.2740450207

Finnigan, T. J. A., Lewis, M. J., \& Dietz, M. (1989). Detoxification of Commercial United Kingdom Rapeseed Meal By Glucosinolate Hydrolysis with Exogenous Myrosinase and the Extractability of the Aglucones by Aqeous Industrial Methylated Spirits. Journal of Science Food and Agriculture, 46, 1-37. http://dx.doi.org/10.1002/jsfa.2740460311

Ibiyemi, S. A., Fadipe, V. O., Akinremi, O. O., \& Bako, S. S. (2002). Variation in oil Composition of Thevetia peruviana Juss (Yellow Oleander) fruits seed. Journal of Applied Science and Environmental Management, $6(2), 61-65$.

Ibiyemi, S. A., \& Oluwaniyi, O. O. (2003). Efficacy of catalysts in the batch esterification of the fatty acids of T. Peruviana seed oil. Journal of Applied Science and Environmental Management, 7(1), 15-17.

Lutz, C., \& Pryztulski, K. (2008). Nutrition and Diet Therapy (p. 236). New Delhi: Jaypee Brothers Medical Publishers.

Oderinde, R. A., \& Oladimeji, G. R. (1990). Oil characteristics of Thevetia peruviana (yellow oleander) and Plumeria alba (White frangipani). Rivista Hahana delle Sostanza Grasse, 67(12), 635-637.

Olomu, J. M. (2011). Monogastric Nutrition. Principles and Practice. Nigeria: Jachem Pub.

Oluwaniyi, O. O., Ibiyemi, A. S., \& Usman, A. L. (2007). Effect of detoxification on the Nutrient content of Thevetia peruviana seed cake. Russian Journal of Applied Science, 2(2), 188-191.

Pauzenga. (1985). Feeding parent stock. Zoo Technical International (pp. 22-23).

SAS. (1999). Statistical Analysis Software. SAS User's Guide Statistic version 6 (4th ed.). Cary.NC: SAS Institute Inc.

Vasudevan, D., Seekumari, S., \& Kannan, V. (2011). Textbook of Biochemistry for Medical Students (6th Ed.). Jaypee Brothers Medical Publ. (P) Ltd.

Verma, D. N. (2006). A textbook of Animal Nutrition (pp. 386-414. 2nd ed.). India: kalyani Publishers.

\section{Copyrights}

Copyright for this article is retained by the author(s), with first publication rights granted to the journal.

This is an open-access article distributed under the terms and conditions of the Creative Commons Attribution license (http://creativecommons.org/licenses/by/3.0/). 